Scientia Marina 71(1)

March 2007, 5-14, Barcelona (Spain)

ISSN: 0214-8358

\title{
Spatial distribution, density, and relative growth of Microphrys bicornutus (Latreille, 1826) (Brachyura: Majidae) in five biotopes in a Thalassia complex
}

\author{
CARLOS A. CARMONA-SUÁREZ
}

Centro de Ecología, Instituto Venezolano de Investigaciones Científicas (IVIC), Apartado 21827,

Caracas 1020A, Venezuela. E-mail: ccarmona@ivic.ve

\begin{abstract}
SUMMARY: Spatial distribution, population density, number of ovigerous females, and relative growth of Microphrys bicornutus were studied in an extremely shallow Thalassia complex (Buchuaco- Venezuela). Monthly sampling was undertaken in 5 different biotopes (zones) (July 1988 to December 1990). Zone 3 (coral rubble) was the least populated by $M$. bicornutus. The highest densities were found in Zones 1 (coral rubble and macro algae) and 4 (Thalassia and calcareous algae). Crab size ranged between 1.86 and $35.40 \mathrm{~mm}$ (carapace length). The largest mean size was found in Zones 2 and 5 , and the smallest in Zone 1. The least mean percentage of ovigerous females was found in Zone 3, and the highest in Zone 5. There were strong temporal fluctuations, with the absence of ovigerous females in the first months of each year. The biometric data showed that pre-pubertal males ranged from 1.80 to $24.20 \mathrm{~mm}$ carapace length, and post-pubertals from 15.16 to 26.15. Pre-pubertal females ranged from 3.16 to 20.25 and post-pubertals from 8.84 to 21.85 . Zone 3 was the most inadequate biotope for M. bicornutus, as it had the lowest density and the least mean percentage of ovigerous females. Zone 4 was the most appropriate biotope. Temporal absence of ovigerous females and the small sizes of the crabs in Buchuaco could be due to extreme environmental conditions.
\end{abstract}

Keywords: Crustacea, Brachyura, spider crabs, Microphrys bicornutus, spatial distribution, population density, relative growth.

RESUMEN: DistRIBUCIÓN ESPACIAL, DENSIDAD Y CRECIMIENTO RELATIVO DE MICROPHRYS BICORNUTUS (LATREILLE, 1826) (BRACHYURA: MAJIDAE) EN CINCO BIOTOPOS DE UN COMPLEJO DE THALASSIA. - Se estudió la distribución espacial, densidad poblacional, número de hembras ovadas, y crecimiento relativo de Microphrys bicornutus en un complejo de Thalassia extremadamente somero (Buchuaco- Venezuela). Se hicieron muestreos mensuales en 5 biotopos diferentes (zonas) (de julio de 1988 a diciembre 1990). La Zona 3 (cascajos de coral) fue la menos poblada. Las mayores densidades se encontraron en las Zona 1 (cascajos de coral y macroalgas) y 4 (Thalassia y algas calcáreas). El tamaño varió entre 1.86 y $35.40 \mathrm{~mm}$ (largo de caparazón). Los mayores tamaños se encontraron en las Zonas 2 y 5 , y los más pequeños en la Zona 1 . El menor porcentaje de hembras ovadas se encontró en la Zona 3, y el mayor en la Zona 5. Hubo grandes fluctuaciones temporales, con la ausencia de hembras ovadas en los primeros meses de cada año. De los datos de biometría, los machos prepubertarios midieron desde 1.80 a $24.20 \mathrm{~mm}$ (largo de caparazón), y los postpubertarios desde 15.16 a 26.15. Las hembras prepubertarias midieron desde 3.16 a 20.25 , y las postpubertarias desde 8.84 a 21.85 . La Zona 3 fue el biotopo más inadecuado para $M$. bicornutus, debido a la menor densidad y el menor porcentaje de hembras ovadas. La Zona 4 fue el biotopo más adecuado. $\mathrm{La}$ ausencia temporal de hembras ovadas y el menor tamaño de los cangrejos en Buchuaco pueden ser debido a condiciones extremas ambientales.

Palabras claves: Crustacea, Brachyura, cangrejos araña, Microphrys bicornutus, distribución espacial, densidad poblacional, crecimiento relativo. 


\section{INTRODUCTION}

There are numerous publications that deal with the spatial distribution of marine organisms at the community and species levels. For instance, fish assemblages, macroinvertebrates, and specifically Mithraculus spp. communities, have been well described in seagrass (Thalassia testudinum) beds. Several factors have been given to explain the spatial distribution of crustacean decapods. Salinity gradients (Norse and Estevez, 1977; Norse, 1978a, 1978b), content of organic matter and sediment texture (Fransozo et al., 1992; Mantelatto, 2000), degree of exposure to wave action (Murphy and Fonseca, 1995; Martínez Iglesias and García Raso, 1999; Carmona-Suárez, 2000), and moulting stage (Ryer et al., 1990), are considered to be some of the features that could explain the population and community distribution of several decapod species.

The State of Falcón (Venezuela) is situated in a region characterized by abnormally arid conditions (Lahey, 1973), where rainfall is scarce and nutrients are low. On its coasts, coral reefs are confined to two areas: Morrocoy National Park, and the coastal strip between Adícora and El Supí - Paraguaná Peninsula (Carmona and Conde, 1989). Furthermore, Thalassia seagrass-beds are also found in the abovementioned areas, and in two other localities situated in the Paraguaná Peninsula (Carmona and Conde, 1989). In the State of Falcón, stunted growth and marked seasonal reproduction of several Brachyura have been observed and hypothesized to be correlated to extreme environmental factors (Conde et al., 1989; Conde and Díaz, 1992; Carmona-Suárez, 1992, 2000).

The decorator crab Microphrys bicornutus has a geographical distribution that ranges from Beaufort (North Carolina, USA) to Santa Catarina (Brazil) (Williams, 1984). It is a frequent inhabitant of Thalassia meadows, as well as coral reefs and red mangrove roots (Heck, 1977; Lemaitre, 1981; Williams, 1984; Carmona-Suárez and Conde, 1996; López-Greco et al., 2000). A number of papers deal with several aspects of the biology and ethology of this crab. For instance, decorating behaviour has been well described by Getty and Hazlett (1978), Guzmán (1979), and Kilar and Lou (1984), as well as agonistic postures and distance separation between congeners (Hazlett, 1972, 1979). Kilar and Lou (1986) also indicate the importance of the camouflaging material in the diet of M. bicornutus. In addition, Hartnoll (1965) refers to several biological characteristics, including relative growth and reproductive aspects. However, few works deal with population aspects of this spider crab, and is only approached to some extent by Carmona-Suárez (1992) and López-Greco et al. (2000).

The purpose of this work is to establish the spatial distribution and elucidate the possible factors that induce it, as well as to determine population density variations between different biotopes, and give more details concerning relative growth and reproduction of the decorator crab Microphrys bicornutus living in an extremely shallow Thalassia complex. Finally, an attempt will be made to show what effects the extreme shallowness of the area has upon the population of this species.

\section{MATERIALS AND METHODS}

\section{Sampling area}

An area of $7700 \mathrm{~m}^{2}$ was selected at the location of Buchuaco $\left(11^{\circ} 59^{\prime} \mathrm{N}, 69^{\circ} 49^{\prime} \mathrm{W}\right)$, on the eastern coast of the Paraguaná Peninsula (State of Falcón, Venezuela) (Fig. 1). It is made up of a Thalassia complex, delimited on the eastern side (ocean side) by a fringing coral reef, which protects the complex from the strong waves that predominate in the area.

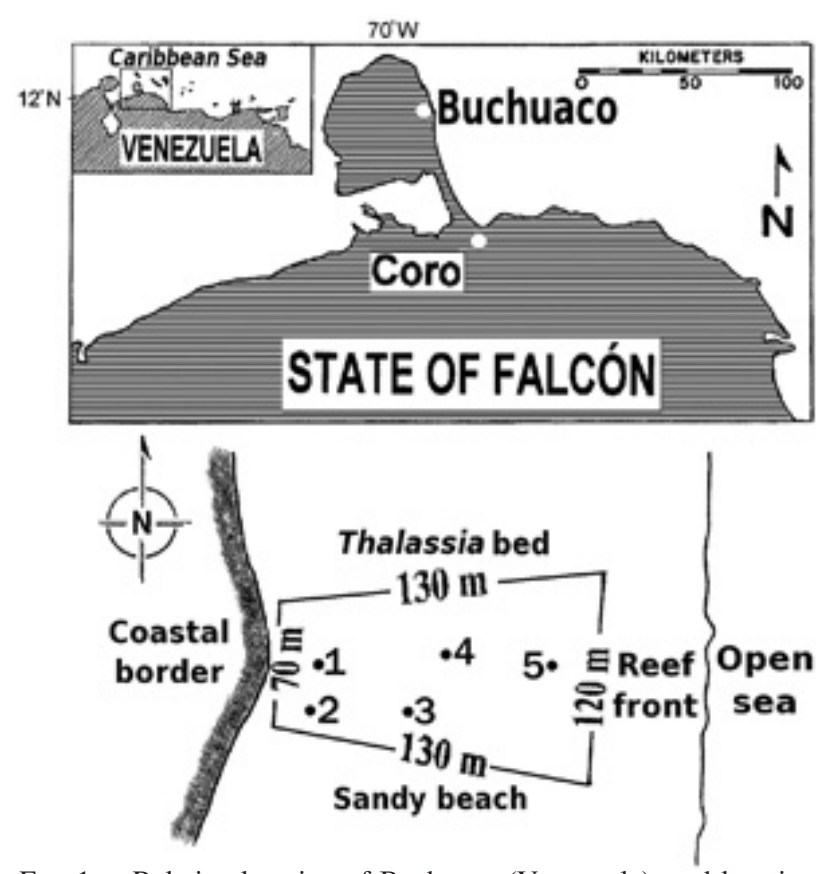

FIG. 1. - Relative location of Buchuaco (Venezuela), and location of the sampling sites. $1=$ Zone $1 ; 2=$ Zone $2 ; 3=$ Zone $3 ; 4=$ Zone 4 ; $5=$ Zone 5 
On the northern side the Thalassia complex extends itself for several tens of meters; a shallow sandy beach delimits the southern side, and the western side is defined by the coastal border (Fig. 1). The whole sampling site is extremely shallow and does not exceed $70 \mathrm{~cm}$ deep. Five different sampling zones were chosen: Zone 1 (approx. $5 \times 5 \mathrm{~m}$ ), composed mainly of dead coral rubble and macro-algae; Zone 2 (5x4 m), with Thalassia testudinum and dead coral rubble; Zone 3 (3x8 m), dead coral rubble; Zone $4(6 \times 6 \mathrm{~m})$, Thalassia and calcareous algae, distant from the reef; and Zone $5(6 \times 6 \mathrm{~m})$, also with Thalassia and calcareous algae, but near the reef.

\section{Physicochemical parameters}

The following physicochemical parameters were measured every month: water temperature, salinity, and variations in the sea level from April 1988 to July 1991, and dissolved oxygen from April 1988 to December 1990. Salinity was measured with a temperature compensated refractometer; temperature and dissolved oxygen with an $\mathrm{YSI}^{\circledR}$ dissolved oxygen meter. A permanent graduated (in $\mathrm{cm}$ ) post fixed to the sea bottom was used to measure the sea level. The graduated post ranged from $0 \mathrm{~cm}$ at the top, to $70 \mathrm{~cm}$ at the bottom; thus, measures are shown as negative numbers. In order to take more accurate readings, and to reduce the effects of water level oscillations caused by wave action, a hollow plastic bucket was placed around the post. Measurements were taken at $9 \mathrm{am}, 12 \mathrm{pm}, 3 \mathrm{pm}$ and $5 \mathrm{pm}$.

\section{Sampling}

Monthly sampling was carried out manually in each of the selected biotopes, using a $0.25 \mathrm{~m}^{2}$ quadrate thrown haphazardly in each zone 5 to 6 times, from July 1988 to December 1990. It was considered appropriate to use a $50 \times 50 \mathrm{~cm}$ square as sampling area due to the fact that Microphrys bicornutus exhibits a terminal anecdysis (Hartnoll, 1965), does not exceed an adult carapace length of 35.5 mm (see Carmona-Suárez, 1992, for review), shows a high degree of site attachment (Hazlett, 1979), and is a species which exhibits very slow movements. Almost all the biota (Thalassia, algae, and/or coral rubble) that was present on the surface of the sea bottom within the quadrate, was removed and thoroughly inspected. Captured animals were counted in the field, measured (carapace length) with a preci- sion $(+/-0.1 \mathrm{~mm})$ caliper, their sex determined, and number of ovigerous females determined. Afterwards, they were returned to their environment. For the biometrical analysis additional captures outside the sampling areas were undertaken. These individuals were brought to the laboratory, where their carapace length (in both sexes), chela width (in males) and abdomen width (in females) were measured in order to apply regression analysis to determine relative growth and sexual maturity, following the methodology used by several authors for brachyuran crabs (Pinheiro and Fransozo, 1993; Sampedro et al., 1999; Carmona-Suárez, 2003). Post-pubertal males were identified by observing the propodite of the chelipeds: these have an additional tooth in the internal border, which is absent in pre-pubertal males (Hartnoll, 1965; CarmonaSuárez, 1992). Post-pubertal females are different from pre-pubertal females by having an almost round abdomen.

\section{Statistical Analysis}

After testing for normality and homogeneity, data that did not meet these criteria (even when logtransformed) were analyzed with nonparametric statistics. Population densities, body size of males, females and all crabs, and mean percentages of ovigerous females between sampling zones, were compared with the Mann-Whitney (W) test. An RxC test was performed to compare sex ratios between zones during each sampling year and for the total sampling period (Sokal and Rohlf, 1995). Furthermore, separate logistic regressions were applied for males and females in order to establish their size at sexual maturity (carapace length at which $50 \%$ of the animals in each of the sexes is mature) (Sampedro et al., 1999; Mura et al., 2005). Most of the statistical analyses were performed with the computer programs Statgraphics Plus 5.0 and Satistica' 99 Edition. Biometrical analyses were carried out using the least square method (Sokal and Rohlf, 1995).

\section{RESULTS}

\section{Physicochemical parameters}

Salinity showed a mean of $36.8(n=41, S D=$ $1.10)$. Although there were no extreme variations in 
salinity (range 34 to 40 ), there were clear peaks in September 88 (39), June 89 (38), December 89 (38), January 91 (38) and May 91 (40) (Fig. 2). The lowest values (34) were found in August 90. In spite of this, no periodicity in salinity variations was detected. Water temperature ranged between 24.0 and $30.0^{\circ} \mathrm{C}(\mathrm{n}=40$, mean $=27.10, \mathrm{SD}=1.50)$ and showed periodical fluctuations (Fig. 2), with peaks in April $88\left(30^{\circ} \mathrm{C}\right)$, September $88\left(29.5^{\circ} \mathrm{C}\right)$, September 89 $\left(28.5^{\circ} \mathrm{C}\right)$, August $\left(29^{\circ} \mathrm{C}\right)$ and October $90\left(29^{\circ} \mathrm{C}\right)$, and July $91\left(30^{\circ} \mathrm{C}\right)$. The lowest temperatures were detected in January $89\left(25^{\circ} \mathrm{C}\right)$, February $90\left(24^{\circ} \mathrm{C}\right)$, and January $91\left(25^{\circ} \mathrm{C}\right)$. Although dissolved oxygen was not measured during all the sampling months, it had a mean of $6.68 \mathrm{mg} \mathrm{O}_{2} / 1(\mathrm{n}=27, \mathrm{SD}=1.82$, min= 4.30 , $\max =11.20$ ), and peaks occurred in May 88 (8.6 $\left.\mathrm{mg} \mathrm{O}_{2} / \mathrm{l}\right)$, January $89\left(11.2 \mathrm{mg} \mathrm{O}_{2} / \mathrm{l}\right)$, July 89 $\left(9.3 \mathrm{mg} \mathrm{O}_{2} / \mathrm{l}\right)$, July $90\left(9.6 \mathrm{mg} \mathrm{O}_{2} / \mathrm{l}\right)$ and October 90 (10.6 $\mathrm{mg} \mathrm{O}_{2} / \mathrm{l}$ ) (Fig. 2).

Mean, maximum and minimum seawater levels were calculated from each monthly measurement (Fig. 3). Peaks were observed in November 88, September 89, and October 90. However, extremely low levels were detected in April 89, February 90, and July 91. In general, water level variations displayed gradual increases towards the last months of the year, and these gradually decreased towards the first months. Due to the extremely shallow conditions of the area, the sea-bottom was exposed to the air during low water levels from 2 to 9 hours. Below the $-38 \mathrm{~cm}$ mark, several sampling zones began to be exposed: Zone 3 , when the sea level reached the $-38 \mathrm{~cm}$ mark; Zone 2 at -44 $\mathrm{cm}$; Zones 4 and 5 at $-48 \mathrm{~cm}$; and Zone 1 at -54 $\mathrm{cm}$. On April 2 1991, due to extremely low water levels $(-52$ to $-62 \mathrm{~cm})$, almost all the sampling

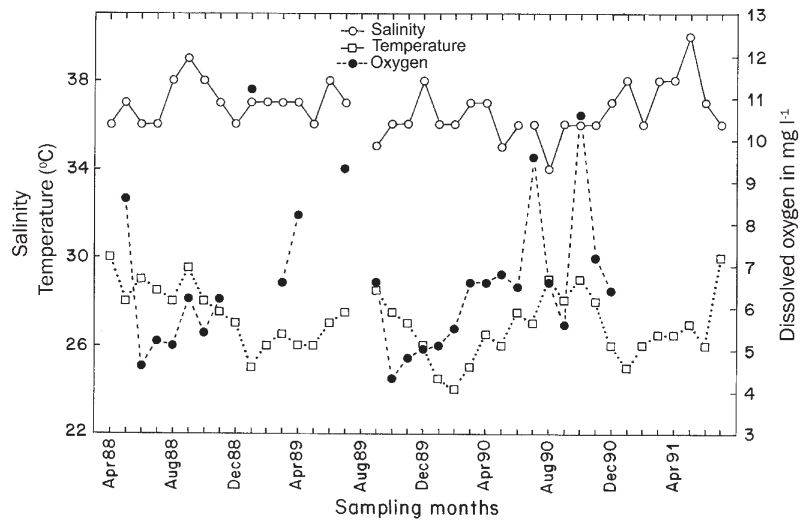

FIG. 2. - Salinity, water temperature $\left({ }^{\circ} \mathrm{C}\right)$ and dissolved oxygen ( $\mathrm{mg} / \mathrm{l})$ variations measured in Buchuaco (Venezuela).

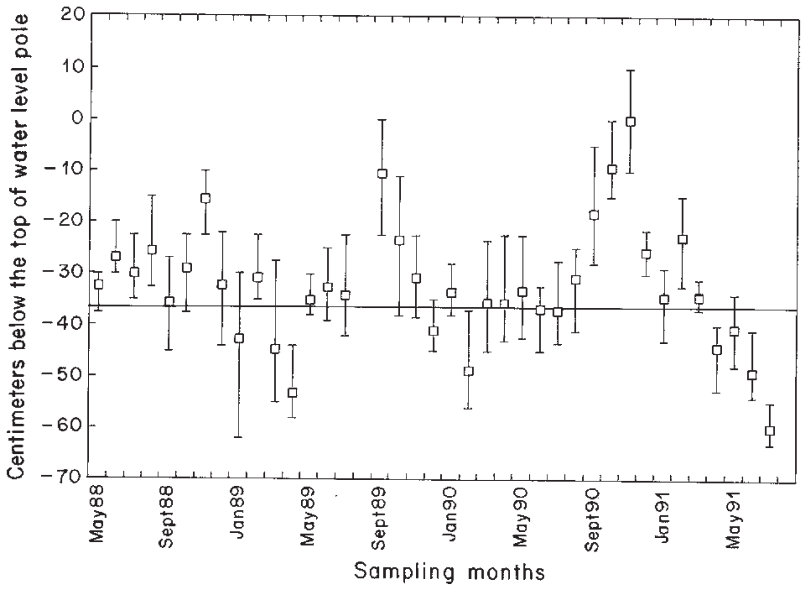

FIG. 3. - Sea level variations (in cm from the top of the pole) measured in Buchuaco (Venezuela). Thick horizontal line marks the sea level at which the bottom begins to be exposed to the air. Box= mean; upper tick= maximum monthly sea level measurement; lower tick= minimum sea level measurement.

areas were exposed to the air. No winds were blowing at the time, water temperatures increased up to $34^{\circ} \mathrm{C}$, and salinity reached 40 . Dissolved oxygen could not be measured. After 3 pm, considerable quantities of diverse animals appeared either dead or moribund, such as: fish (Abudefdus saxatilis, surgeonfish, scorpionfish, moray eels), sea cucumbers, crabs (Callapidae, Portunidae, Xanthidae), the gastropod Aplysia sp., the sea urchin Diadema antillarum, and sedentary polychaetes among others. Most of the exposed Thalassia was dry on the upper part.

\section{Population density, sex relationship, body size and reproduction}

Total density (all sampling sites together) had a grand mean of $1.7 \mathrm{crabs} / 0.25 \mathrm{~m}^{2}$ (Table 1 ). The highest densities appeared in Zone 1 and Zone 4. The lowest values were found in Zone 3. Significant differences were found in the densities between the zones

TABLE 1. - Population density of Microphrys bicornutus in the different sampling zones in Buchuaco (Venezuela). Density given in number of animals per $0.25 \mathrm{~m}^{2} . \mathrm{n}=$ number of quadrates; $\mathrm{SD}=$ standard deviation.

\begin{tabular}{lcrrr}
\hline & $\mathrm{n}$ & Mean & Range & SD \\
\hline Zone1 & 26 & 2.1 & $0-9.3$ & 2.66 \\
Zone2 & 27 & 1.4 & $0-5.0$ & 1.48 \\
Zone3 & 23 & 0.7 & $0-2.2$ & 0.79 \\
Zone4 & 29 & 2.5 & $0.1-8.0$ & 1.84 \\
Zone5 & 29 & 1.4 & $0-4.5$ & 1.05 \\
All & 134 & 1.7 & $0.1-9.3$ & 1.78 \\
\hline
\end{tabular}


TABLE 2. - Number of individuals of Microphrys bicornutus collected within quadrates in each of the sampling zones during the period 1988-1990, in Buchuaco (Venezuela).

\begin{tabular}{|c|c|c|c|c|}
\hline & Males & Females & Undefined & Totals \\
\hline \multicolumn{5}{|l|}{1988} \\
\hline Zone 1 & 28 & 22 & 2 & 52 \\
\hline Zone 2 & 51 & 46 & 6 & 103 \\
\hline Zone 3 & 16 & 22 & 7 & 45 \\
\hline Zone 4 & 37 & 35 & 4 & 76 \\
\hline Zone 5 & 21 & 15 & 8 & 44 \\
\hline Total & 153 & 140 & 27 & 320 \\
\hline \multicolumn{5}{|l|}{1989} \\
\hline Zone 1 & 20 & 24 & 3 & 47 \\
\hline Zone 2 & 38 & 25 & 3 & 66 \\
\hline Zone 3 & 19 & 13 & 5 & 37 \\
\hline Zone 4 & 78 & 82 & 23 & 183 \\
\hline Zone 5 & 42 & 47 & 3 & 92 \\
\hline Total & 197 & 191 & 37 & 425 \\
\hline \multicolumn{5}{|l|}{1990} \\
\hline Zone 1 & 116 & 101 & 20 & 237 \\
\hline Zone 2 & 30 & 35 & 2 & 67 \\
\hline Zone 3 & 1 & 2 & 0 & 3 \\
\hline Zone 4 & 104 & 102 & 6 & 212 \\
\hline Zone 5 & 48 & 43 & 2 & 93 \\
\hline Total & 299 & 283 & 30 & 612 \\
\hline Grand Total & 649 & 614 & 94 & 1357 \\
\hline
\end{tabular}

(Kruskal-Wallis test: $\mathrm{H}=21.45 ; \mathrm{p}<0.0002)$. Paired comparisons (Mann-Whitney test) between sampling zones revealed significant differences between Zone 3 and all other zones $\left(\mathrm{W}=170.5^{*}\right.$ for Zone $1 ; \mathrm{W}=$ $207.5^{*}$ for Zone $2 ; \mathrm{W}=691.5^{* * *}$ for Zone $4 ; \mathrm{W}=$ $484.0 * * *$ for Zone 5). Furthermore, statistical differences were found between Zones 2 and $4(\mathrm{~W}=684.5)$, and between Zones 4 and $5(\mathrm{~W}=312.5)$.

During population density measurements, a total of 1357 crabs (649 males, 614 females, and 94 undefined) were collected in a period of 30 sampling months (Table 2). No deviations from the Mendelian proportion were found in the sex relationship during the whole sampling period, or in any of the sampled zones or years (all G- tests were non-significant at $\mathrm{p}>0.05$ ).

The size of all sampled animals ranged between 1.86 and $35.40 \mathrm{~mm}$ (carapace length) (mean= 8.59; $\mathrm{SD}=4.34 ; \mathrm{n}=1263)$. Descriptive statistics of animal
TABLE 4. - Comparison of sizes (carapace length in $\mathrm{mm}$ ) in the different sampling zones in Buchuaco (Venezuela). Values correspond to the Mann-Whitney test (W); a) all animals; b) females; c) males.

\begin{tabular}{lcccc}
\hline & Zone 2 & Zone 3 & Zone 4 & Zone 5 \\
\hline a) & & & & \\
Zone 1 & $40552.0(* * *)$ & $11143.0(\mathrm{~ns})$ & $67210.5(\mathrm{~ns})$ & $40919.5(* * *)$ \\
Zone 2 & - & $7133.5(\mathrm{~ns})$ & $40853.5(* * *)$ & $26024.0(\mathrm{~ns})$ \\
Zone 3 & & - & $16410.0(\mathrm{~ns})$ & $9224.0(*)$ \\
Zone 4 & & & - & $57598.5(* * *)$ \\
b) & & & & \\
Zone 1 & $9987.0(* * *)$ & $3177.5(\mathrm{~ns})$ & $16191.0(\mathrm{~ns})$ & $10301.5(* * *)$ \\
Zone 2 & - & $1952.5(\mathrm{~ns})$ & $8616.0(* * *)$ & $6027.0(\mathrm{~ns})$ \\
Zone 3 & & - & $3531.5(\mathrm{~ns})$ & $2067.5(\mathrm{~ns})$ \\
Zone 4 & & & - & $15060.5(* * *)$ \\
c) & & & & \\
Zone 1 & $10407.0(\mathrm{~ns})$ & $2368.0(\mathrm{~ns})$ & $17245.5(\mathrm{~ns})$ & $10174.5(\mathrm{~ns})$ \\
Zone 2 & - & $1611.5(*)$ & $11547.5(\mathrm{~ns})$ & $6981.0(\mathrm{~ns})$ \\
Zone 3 & & - & $4617.5(\mathrm{~ns})$ & $2561.5(*)$ \\
Zone 4 & & & - & $13928.5(*)$ \\
\hline
\end{tabular}

size of males, females and totals for each of the sampling zones are shown in Table 3. The mean size of the total number of crabs was largest in Zone 5, and smallest in Zone 1 . There were significant differences in total crab size between Zones 1 and 2,1 and 5 , as well as between 2 and 4, 3 and 5, and 4 and 5 (Table 4a). Significant differences in female size were found between Zones 1 and 2,1 and 5,2 and 4 , and between 4 and 5 (Table 4b). The mean size of females was largest in Zone 5, and smallest in Zone 1 (Table 3 ). Male size differed significantly between Zones 2 and 3, 3 and 5, and 4 and 5 (Table 4c). The largest males (mean size) were found in Zone 5, whilst the smallest mean size was found in Zone 3 (Table 3).

Ovigerous females were present in all the sampling zones, showing a grand mean of $68.9 \%(n=$ 134; $\mathrm{SD}=33.68$ ). The least mean percentage of ovigerous females was found in Zone $3(n=23$; mean $=24.0 ; \mathrm{SD}=41.85$ ), and the highest in Zone 5 $(n=29$; mean $=58.9 ; \mathrm{SD}=46.71)$. Significant differences (Mann-Whitney test) were found between Zones 2 and $3\left(\mathrm{~W}=209.5^{*}\right)$, as well as between

TABLE 3. - Body size (carapace length in $\mathrm{mm}$ ) of Microphrys bicornutus in the different sampling zones of Buchuaco (Venezuela); $\mathrm{n}=$ number of crabs; $\mathrm{SD}=$ standard deviation.

\begin{tabular}{|c|c|c|c|c|c|c|c|c|c|c|c|c|}
\hline & \multicolumn{4}{|c|}{ All animals } & \multicolumn{4}{|c|}{ Females } & \multicolumn{4}{|c|}{ Males } \\
\hline & $\mathrm{n}$ & Mean & SD & Size range & $\mathrm{n}$ & Mean & $\mathrm{SD}$ & Size range & $\mathrm{n}$ & Mean & SD & Size range \\
\hline Zone 1 & 311 & 8.04 & 3.88 & $1.86-20.00$ & 147 & 8.30 & 3.76 & $1.86-20.00$ & 164 & 7.81 & 3.98 & $2.16-19.82$ \\
\hline Zone 2 & 225 & 9.12 & 4.04 & $1.94-19.10$ & 106 & 10.15 & 3.86 & $1.94-18.00$ & 119 & 8.20 & 3.99 & $2.30-21.30$ \\
\hline Zone 3 & 73 & 8.62 & 5.44 & $2.30-21.30$ & 37 & 10.15 & 5.57 & $3.00-19.92$ & 36 & 7.05 & 4.90 & $2.30-36.00$ \\
\hline Zone 4 & 438 & 8.14 & 4.37 & $2.09-35.40$ & 219 & 8.49 & 4.02 & $2.38-20.40$ & 219 & 7.79 & 4.68 & $2.09-35.40$ \\
\hline Zone 5 & 216 & 9.73 & 4.53 & $2.24-22.88$ & 105 & 10.77 & 4.35 & $2.24-19.48$ & 111 & 8.74 & 4.50 & $2.50-22.88$ \\
\hline Total & 1263 & 8.59 & 4.34 & $1.86-35.40$ & 614 & 9.22 & 4.21 & $1.86-20.40$ & 649 & 7.99 & 4.38 & $2.09-35.40$ \\
\hline
\end{tabular}




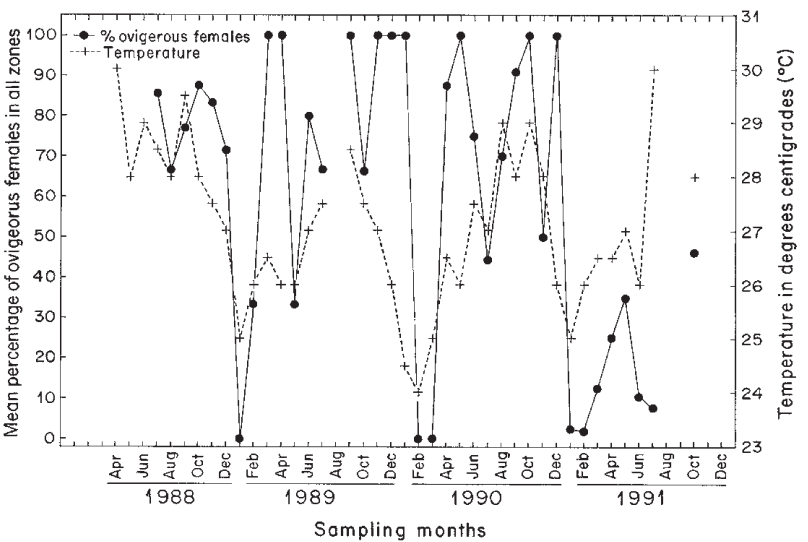

FIG. 4. - Percentage of ovigerous females of Microphrys bicornutus and surface temperature $\left({ }^{\circ} \mathrm{C}\right)$ variations measured in Buchuaco (Venezuela).

Zones 3 and $5(\mathrm{~W}=469 * *)$. The range in all the zones varied between $0 \%$ and $100 \%$, thus showing periods where ovigerous females were completely absent (Fig. 4). There were high fluctuations during the entire sampling period, but no rhythmicity was detected. Nevertheless, ovigerous females were absent at the lowest temperatures (January 89; February- April 90; January- February 91) (Fig. 4), and they were significantly correlated with surface water temperature $(\%$ ovigerous females $=-251.7+$ $11.754 x$ Temperature; $\mathrm{n}=37, \mathrm{p}<0.05)$.

\section{Relative growth}

Four hundred and five males and 422 females were captured for biometrical analyses. Pre-pubertal males ranged between 1.80 and $24.20 \mathrm{~mm}$ carapace length $(n=281 ;$ Mean $=10.74 ; \mathrm{SD}=6.01)$, whilst post-pubertal males ranged between 15.16 and $26.15(\mathrm{n}=88 ;$ Mean=21.39; $\mathrm{SD}=2.55)$. The molt of

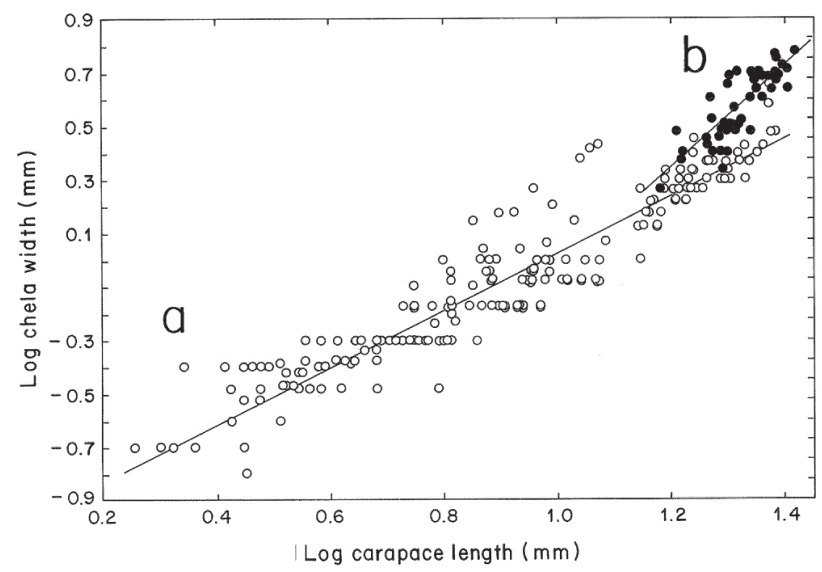

FIG. 5. - Relative growth of pre-pubertal (a) and post-pubertal (b) male Microphrys bicornutus in Buchuaco (Venezuela).

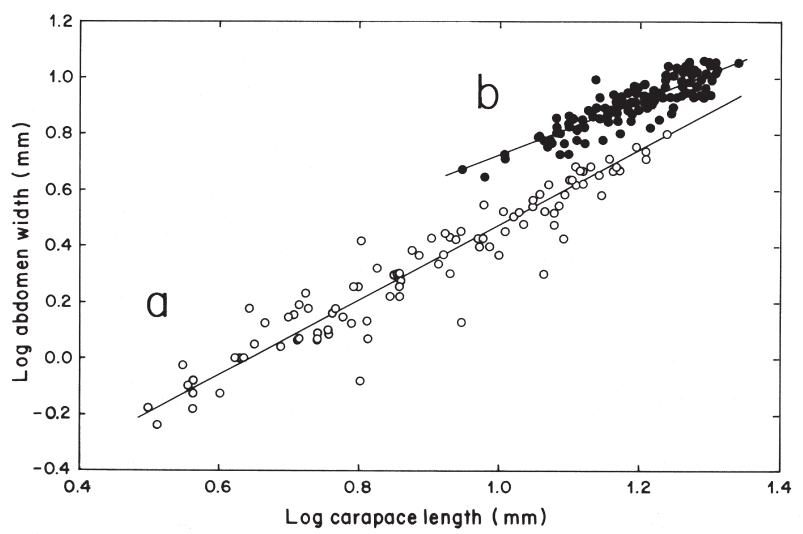

FIG. 6. - Relative growth of pre-pubertal (a) and post-pubertal (b) female Microphrys bicornutus in Buchuaco (Venezuela).

TABLE 5. - Relative growth in Microphrys bicornutus. Regression lines of carapace length (CL) against chela width $(\mathrm{CW})$ of prepubertal and post-pubertal males, and CL against abdomen width (AW) of pre-pubertal and post-pubertal females. Measurements in $\mathrm{mm}$ were log-transformed.

\begin{tabular}{|c|c|c|c|c|}
\hline & Regression equation & $\mathrm{n}$ & $\mathrm{r}$ & $\mathrm{p}$ \\
\hline \multicolumn{5}{|l|}{ Males } \\
\hline Pre-puberty & $\log C W=-1.044+1.070 * \log C L$ & 281 & 0.950 & $<0.005$ \\
\hline Post-puberty & $\log C W=-1.957+1.918 * \log C L$ & 88 & 0.815 & $<0.005$ \\
\hline \multicolumn{5}{|l|}{ Females } \\
\hline Pre-puberty & $\log A W=-0.862+1.339 * \log C L$ & 138 & 0.960 & $<0.005$ \\
\hline Post-puberty & $\log A W=-0.250+0.969 * \log C L$ & 283 & 0.884 & $<0.005$ \\
\hline
\end{tabular}

puberty in males takes place between 15.14 and $23.26 \mathrm{~mm}$ carapace length (Fig. 5), with a significant change in the slope from 1.07 to $1.92(\mathrm{~F}=$ 507.13; $\mathrm{DF}=365 ; \mathrm{p}<0.001)$. Pre-pubertal females ranged between 3.16 and $20.25 \mathrm{~mm}$ carapace length $(\mathrm{n}=138$; Mean= 9.41; $\mathrm{SD}=3.91)$, whilst post-pubertal females ranged between 8.84 and $21.85(n=283$; Mean $=16.23 ; \mathrm{SD}=2.56$ ). The molt of puberty in females takes place between 8.84 and $20.18 \mathrm{~mm}$ carapace length (Fig. 6), with a significant change in the slope from 1.33 to $0.97(\mathrm{~F}=105.24 ; \mathrm{DF}=418$; $\mathrm{p}<0.001)$. Regression equations for both sexes are shown in Table 5. Logistic regressions showed that $50 \%$ of males reached morphological maturity at a carapace length of 19.88, and females at $12.00 \mathrm{~mm}$ carapace length (Fig. 7).

\section{DISCUSSION}

In overall, Microphrys bicornutus density in the extremely shallow Thalassia habitat was very low $\left(1.76 \mathrm{crabs} / 0.25 \mathrm{~m}^{2}\right)$. Highest densities were found 


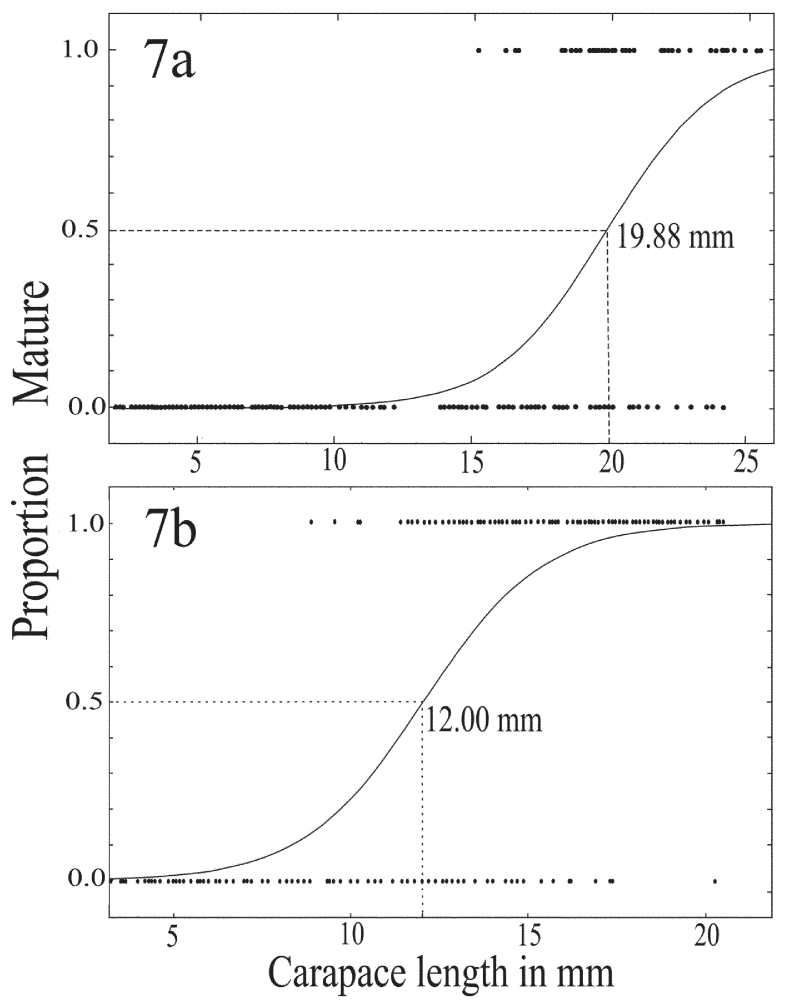

FIG. 7. - Estimated size at 50\% morphological maturity (SMm) for Microphrys bicornutus in Buchuaco (Venezuela): $\mathrm{a}$, males (SMm= $19.88 \mathrm{~mm} \mathrm{CL})$; b, females $(\mathrm{SMm}=12.00 \mathrm{~mm} \mathrm{CL})$.

in Zones 1 and 4, and Zone 3 was the least populated area. The lowest population density in the latter zone may be explained by the fact that this area is almost entirely deprived of plants and other animals, therefore offering little food and decoration resources for this masking crab. Furthermore, this area is the shallowest of all, and is the first to be exposed to the air when the water level declines, thus experiencing greater environmental fluctuations. Although there are significant differences in crab density between Zones 4 and 5, these two zones have almost the same biotope composition (Thalassia and calcareous algae); however, the reasons for these differences are not clear. Speculatively, they may be related to the proximity of Zone 5 to the coral reef, which is a less protected area than Zone 4. This latter area is situated further away from the reef, and always presented a higher density of Thalassia and calcareous algae. Moreover, due to the proximity of Zone 5 to the reef, coral rubble is often found in this area, which is possibly another factor influencing the population density. Taking into account the mean body size of each sex and of the total of the animals for each sampling zone, Zones 2 and 5 were the areas where the largest animals appeared, although the largest individual was found in Zone 4, whilst the smallest one appeared in Zone 1. It is possible that crabs preferred Zones 1 and 4 because they offer more food and decorative resources, better protection from exposure to the air during extremely low tides (they lay deeper than Zones 2 and 3), and less exposure to high-energy waves.

Hartnoll (1965) states that it was impossible for him to visually separate pre-pubertal from postpubertal males, but in the present work this was not the case. In addition, López-Greco et al. (2000) apparently did not encounter any problems in visually separating pre-pubertal from post-pubertal males. Results on relative growth of $M$. bicornutus in Buchuaco are similar to those presented by López-Greco et al. (2000) for this species on Isla Margarita (Venezuela). For female specimens in both localities, juveniles exhibited positive allometric growth of the abdomen and negative allometric growth in adults. However, even though in males the allometric slope increases from pre-pubertal to postpubertal in both localities, in Buchuaco this change is greater than on Isla Margarita (from 1.07 to 1.92 Buchuaco, and 1.14 to 1.26 Margarita). Furthermore, there are differences in the size of the smallest post-pubertal (SP) males and females between the populations of Buchuaco and Isla Margarita (Table 6). SP males were larger in Buchuaco, but SP females were larger on Isla Margarita. The largest pre-pubertal males (LP) were larger in Margarita, but LP females had almost the same size in both locations.

The presence of ovigerous females did not show a rhythmically fluctuating pattern, but their absence during the months with the lowest temperatures was evident (Fig. 4). This contrasts with the appearance of ovigerous females throughout the year in another location in Venezuela (Isla Margarita; López-Greco et al., 2000), where they ranged from 33.7 to $64.9 \%$ of the total sampled females. Moreover, Hartnoll

TABLE 6. - Size comparison (carapace length in $\mathrm{mm}$ ) of smallest post-pubertal (SP) and largest pre-pubertal (LP) males and females of Microphrys bicornutus between Isla Margarita (López-Greco et $a l ., 2000)$ and Buchuaco (this work).

\begin{tabular}{llcc}
\hline Sex & Locality & SP & LP \\
\hline Males & Margarita & 9.50 & 28.20 \\
Females & Buchuaco & 15.16 & 24.20 \\
& Margarita & 10.65 & 21.60 \\
& Buchuaco & 8.84 & 20.25 \\
\hline
\end{tabular}


(1965) reported that ovigerous females in Jamaica are frequently found from December to July, which indicates that they were present even in the months when they did not appear in Buchuaco. The mean percentage of ovigerous females was lowest in Zone 3 , but significantly different only in Zones 2 and 5 . This may be due to the extreme conditions of this biotope, which were explained above when discussing population density differences between the sampling zones.

In tropical regions it is well known that Brachyura (and crustacea in general) breed throughout the year (Hartnoll, 1965; Cobo, 2002a, 2002b), but temperature variations can influence the percentage of ovigerous females during the year, at least in crabs that live in shallow waters, so that the lowest values appear during the lowest temperatures. This has been observed in M. bicornutus (this work), and in another tropical crab, Pilumnus vespertilio (Litulo, 2005). In both species, there is a positive correlation between the percentage of ovigerous females and temperature. Nevertheless, the mechanisms behind how temperature influences the secondary production in tropical crabs have not been clearly examined.

The extremely shallow conditions of the Thalassia complex in Buchuaco seem to be a key factor for explaining different events that occur in the population of Microphrys bicornutus, compared with other studied populations of this species. This has been indicated previously by Carmona-Suárez (1992) for this location, concerning the smaller body size of M. bicornutus compared with other localities in the Caribbean. For instance, López-Greco et al. (2000), dealing with several population features of M. bicornutus on Isla Margarita (Venezuela), report a mean carapace length (CL) of $15.08 \mathrm{~mm}$ for males; whereas Carmona-Suárez (1992) indicates that in Buchuaco mean size was $8.5 \mathrm{~mm}$ CL for the same sex. In the present work males show a similar mean size of $7.99 \mathrm{~mm}$ CL. This confirms the smaller body size of this spider crab, even between locations within the same geographical region (Buchuaco and Isla Margarita). Moreover, in another extremely shallow Thalassia complex (0 to $0.4 \mathrm{~m}$ depth) located in Morrocoy National Park (Venezuela) (between $10^{\circ} 47^{\prime}-10^{\circ} 59^{\prime} \mathrm{N}$, and $68^{\circ} 09^{\prime}$ - $68^{\circ} 22^{\prime} \mathrm{W}$ ), and roughly $214 \mathrm{~km}$ eastward from Buchuaco, ovigerous females of four species of spider crab, from the Genus Mithraculus, have been found to appear only during some months during the year, and are barely present in the sheltered seagrass areas (Carmona-Suárez, 2000). This National Park is well known for its high diversity and the complexity of its coral reefs, mangrove forests and Thalassia meadows, and has been the object of extensive biological and ecological research studies (see Klein and Bone, 1995 for review). It seems therefore obvious to assume that water shallowness may play an important role in the energy budget of these crabs, which is reflected in their poor secondary production, but the mechanisms are still unknown.

Low water levels during the first months of each year (except in 1991, when they occurred between April and July) caused several areas of the complex to be frequently exposed to the air so that the crabs were threatened with desiccation, high temperatures, and deprivation of available dissolved oxygen. This indeed happened in April 1991, when extensive areas were completely exposed to the air for several hours during the day, and winds were totally absent. Water temperature and salinity were higher than normal $\left(34^{\circ} \mathrm{C}\right.$ and 40 respectively). Many organisms that lived buried in the sediment, as well as organisms that were normally not visible during the samplings, were found either dead or almost dead. Physiological effects of air exposure have been described in the decapods Cancer pagurus (Regnault, 1992), C. productus (De Fur and McMahon, 1984) and Panulirus argus (Vermeer, 1987), evidencing an increase in blood ammonia during emersion. This could cause physiological stress that may be reflected in growth and secondary production, and should also be considered in the case of M. bicornutus in Buchuaco.

Mass mortality events are not an uncommon phenomenon. They have been documented at the species and community levels. These catastrophic events can occur due to different reasons, such as diseases (Carpenter, 1990), hurricane effects (Stoddart, 1962; Glynn et al., 1964; Orihuela et al., 1991), a combination of different biological and oceanographic processes (hydrology, meteorological components, high pelagic productivity, pollution) (Stachowitsch, 1984), unusual holomictic conditions (Barić et al., 2003), high temperatures in intertidal areas (Tsuchiya, 1983), or upwelling events and severe salinity declines (Goodbody, 1961; Laboy-Nieves et al., 2001). Nevertheless, in Buchuaco, community mass mortality was most likely induced by depletion of dissolved oxygen due 
to the combined effects of the prolonged exposure of the marine bottom to the air, wind stillness and high day temperatures. Although this event happened only once during over 3 years of field sampling in this area, it shows the fragility of this ecosystem complex and could, in part, explain the smaller sizes of Microphrys bicornutus compared with other populations from the Caribbean (Carmona-Suárez, 1992), the low population densities of this species, and the absence of ovigerous females during the lowest surface temperatures.

Further investigations are necessary in order to clearly establish which mechanisms the population of Microphrys bicornutus is employing to survive in such extreme environmental conditions (exposure to air, high temperatures, and low levels of dissolved oxygen) as those found in Buchuaco, and to understand in general how sublittoral crab populations adapt to living in conditions that are more suitable for intertidal organisms. In this sense, physiological experiments should be carried out to compare thermal and respiration limits in populations that live in locations where environmental conditions are considered normal, and in populations that dwell in extreme environmental conditions which vary greatly.

\section{ACKNOWLEDGEMENTS}

My sincere gratitude to Sebastián Trómpiz (UNEFM- Venezuela), whose invaluable help in the field and laboratory made it possible to gather all the necessary information for this paper, and to Omégar Céspedes (UNEFM- Venezuela) for occasional help in collecting specimens. I also extend my thanks to Jesús Eloy Conde (IVIC), Chris Woods and an anonymous reviewer for their valuable observations of the manuscript. Finally, to Sergio Zambrano (IVIC) for digitally mapping the sampling area. All the fieldwork and laboratory analyses were carried out by the author while working as a staff member of the Centro de Investigaciones Marinas (Universidad Francisco de Miranda - Venezuela).

\section{REFERENCES}

Baelde, P. - 1990. Differences in the structures of fish assemblages in Thalassia testudinum beds in Guadeloupe, French West Indies, and their ecological significance. Mar. Biol., 105: 163-173.

Barić, A., B. Grbec, G. Kušpilić, I. Marasović, Ž. Ninčević and I. Grubelić. - 2003. Mass mortality event in a small saline lake (Lake Rogoznica) caused by unusual holomictic conditions.
Sci.Mar., 67(2): 129-141.

Bitter-Soto, R. - 1999. Benthic communities associated to Thalassia testudinum (Hydrocharitaceae) at three localities of Morrocoy national Park, Venezuela. Rev. Biol. Trop., 47(3): 443-452.

Carmona, C.A. and J.E. Conde. - 1989. Caracterizacion de las costas del estado Falcón, Venezuela. Bol. Inst. Oceanog. de Venezuela Univ. Oriente, 28(1-2): 127-133.

Carmona-Suárez, C.A. - 1992. Interpopulation size variation in a tropical decorator crab, Microphrys bicornutus (Latreille, 1825) (Decapoda, Brachyura, Majidae) Crustaceana, 63(3): 319-322.

Carmona-Suárez, C.A. and J.E. Conde. - 1996. Littoral brachyuran crabs (Crustacea: Decapoda) from Falcón, Venezuela, with biogeographical and ecological remarks. Rev. Brasil. Biol., 56(4): 725-747.

Carmona-Suárez, C.A. - 2000. Differences between Mithraculus spp. communities in exposed and sheltered shallow-water Thalassia beds in Venezuela. Crust. Issues, 12: 419-429.

Carmona-Suárez, C.A. - 2003. Reproductive biology and relative growth of the spider crab Maja crispata (Crustacea: Brachyura: Majidae). Sci. Mar., 67(1): 75-80.

Carpenter, R.C. - 1990. Mass mortality of Diadema antillarum. II. Effects on population densities and grazing intensity of parrotfishes and surgeonfishes. Mar. Biol., 104: 79-86.

Cobo, V.J. - 2002a. Breeding period of the spider crab Mithraculus forceps (A. Milne Edwards) (Crustacea, Majidae, Mithracinae) in the southeastern Brazilian coast. Rev. Bras. Zool., 19 (Supl. 1): $229-234$.

Cobo, V.J. - 2002b. Breeding period of the arrow crab Stenorhynchus seticornis from Couves Island, south-eastern Brazilian coast. J. Mar. Biol. Ass. U.K., 82: 1031-1032.

Conde, J.E. and H. Díaz. - 1989. Productividad de hábitat e historias de vida del cangrejo de mangle Aratus pisonii (H. Milne Edwards) (Brachyura, Grapsidae). Bol. Inst. Oceanog. de Venezuela Univ. Oriente, 28 (1-2): 113-120.

Conde, J.E., H. Díaz and G. Rodríguez. - 1989. Crecimiento reducido en el cangrejo de mangle Aratus pisonii (H. Milne-Edwards) (Brachyura: Grapsidae). Acta Cient. Venez., 40(2): 159-160.

Conde, J.E. and H. Díaz. - 1992. Extension of the stunting range in ovigerous females of the mangrove crab Aratus pisonii $(\mathrm{H}$. Milne Edwards, 1837) (Decapoda, Brachyura, Grapsidae). Crustaceana, 62(3): 319-322.

Conde, J.E., C. Alarcón, S. Flores and H. Díaz. - 1995. Nitrogen and tannins in mangrove leaves might explain interpopulation varations in the crab Aratus pisonii. Acta Cient. Venez., 46: 303-304.

De Fur, P.L. and B.R. McMahon. - 1984. Physiological compensation to short-term air exposure in red rock crabs, Cancer productus Randall, from littoral and sublittoral habitats. II. Acidbase balance. Physiol. Zool., 57: 151-160.

Fransozo, A., M.L. Negreiros-Fransozo, F.M. Mantellato, A. Pinheiro and S. Santos. - 1992. Composição e distribuição dos Brachyura (Crustacea, Decapoda) do sublitoral não consolidado na Enseada da Fortaleza, Ubatuba (SP). Rev. Brasil. Biol., 52(4): 667-675.

Getty, T. and B.A. Hazlett. - 1978. Decoration behaviour in Microphrys bicornutus (Latreille, 1825) (Decapoda, Brachyura). Crustaceana, 34(1): 105-108.

Glynn, P.W., L.R. Almodóvar and J.G. González. - 1964. Effects of hurricane Edith on marine life in La Parguera, Puerto Rico. Carib. J. Sci., 4(2-3): 335-345.

Goodbody, I. - 1961. Mass mortality of a marine fauna following tropical rains. Ecology, 42(1): 150-155.

Guzmán, H.M. - 1979. Comportamiento decorador con algas en el cangrejo Microphrys bicornutus Latreille (Majidae; Decapoda). Rev. Biol. Trop., 27(2): 321-327.

Hartnoll, R.G. - 1965. The biology of spider crabs: a comparison of British and Jamaican species. Crustaceana, 9: 1-16

Hazlett, B. - 1972. Responses to agonistic postures by the spider crab Microphrys bicornutus. Mar. Behav. Physiol., 1: 85-92.

Hazlett, B. - 1979. Individual distance in crustacea: 3 . The spider crab Microphrys bicornutus. Z. Tierpsychol., 49: 65-70.

Heck, K.L. Jr. - 1977. Comparative species richness, composition, and abundance of invertebrates in Caribbean sea-grass (Thalassia testudinum) meadows (Panamá). Mar. Biol., 41: 335-348.

Kilar, J.A. and R.M. Lou. - 1984. Ecological and behavioural stud- 
ies of the decorator crab Microphrys bicornutus Latreille (Decapoda: Brachyura): a test of optimum foraging theory. $J$. Exp. Mar. Biol. Ecol., 74: 157-167.

Kilar, J.A. and R.M. Lou. - 1986. The subtleties of camouflage and dietary preference of the decorator crab, Microphrys bicornutus Latreille (Decapoda: Brachyura). J. Exp. Mar. Biol. Ecol., 101: 143-160.

Klein, E. and D. Bone. - 1995. Ecosistema Morrocoy: Estado actual de las investigaciones y perspectivas futuras. INTECMARU.S.B., Caracas.

Laboy-Nieves, E.N., E. Klein, J.E. Conde, F. Losada, J.J. Cruz and D. Bone. - 2001. Massive mortality of tropical marine communities in Morrocoy, Venezuela. Bull. Mar. Sci., 68(2): 163-179.

Lahey, J.F. - 1973. On the origin of the dry climate in northern South America and the southern Caribbean. In: D.H.Amiran and A.W. Wilson (eds.), Coastal deserts: their natural and human environments, pp. 75-90. The University of Arizona Press, Tucson, Arizona.

Lemaitre, R. - 1981. Shallow-water crabs (Decapoda: Brachyura) collected in the Southern Caribbean near Cartagena, Colombia Bull. Mar. Sci., 31(2): 234-266.

López-Greco, L.S., J.E. Hernández, J. Bolaños, E.M. Rodríguez and G. Hernández. - 2000. Population features of Microphrys bicornutus Latreille, 1825 (Brachyura, Majidae) from Isla Margarita, Venezuela. Hydrobiol., 439: 151-159.

Mantelatto, F.L.M. - 2000. Allocation of the portunid crab Callinectes ornatus (Decapoda: Brachyura) in the Ubatuba Bay, northern coast of São Paulo State, Brazil. Crust. Issues, 12: 431-443.

Martínez Iglesias, J.C. and J.E. García Raso. - 1999. The crustacean decapod communities of three coral reefs from the southwestern Caribbean Sea of Cuba: species composition, abundance and structure of the communities. Bull. Mar. Sci., 65(2): 539-557.

Mura, M., F. Orrù and A. Cau. - 2005. Size at sexual maturity of the spider crab Anamathia rissoana (Decapoda: Majoidea) from the Sardinian Sea. J. Crust. Biol., 25(1): 110-115.

Murphy, P.L. and M.S. Fonseca. - 1995. Role of high and low energy sea-grass beds as nursery areas for Penaeus duorarum in North Carolina. Mar. Ecol. Prog. Ser., 121: 91-98.

Norse, E. A. and M. Estevez. - 1977. Studies on portunid crabs from the Eastern Pacific. I. Zonation along environmental stress gradients from the coast of Colombia. Mar. Biol., 40: 365-373.

Norse, E.A. - 1978a. An experimental gradient analysis: hyposalinity as an "upstress" distributional determinant for Caribbean portunid crabs. Biol. Bull., 155: 586-598.

Norse, E.A. - 1978b. Physicochemical and biological stressors as distributional determinants of Caribbean and eastern Pacific swimming crabs. In: J.H. Thorp and J.W. gibbons (eds.), Energy and environmental stress in aquatic systems, pp. 120140. DOE Symp. Ser. Augusta, Georgia.

O'Gower, A.K. and J.W. Wacasey. - 1967. Animal communities associated with Thalassia, Diplanthera, and sand beds in
Biscayne Bay. I. Analysis of communities in relation to water movements. Bull. Mar. Sci., 17(1): 174-210.

Orihuela, B., H. Díaz and J.E. Conde. - 1991. Mass mortality in a mangrove roots fouling community in a hypersaline tropical lagoon. Biotropica, 23(4b): 592-601.

Pompa, L., A.S. Prieto and R. Manrique. - 1989. Abundancia y distribución espacial en una población del erizo Echinometra lucunter (L) en el Golfo de Cariaco, Venezuela. Acta Cient. Venez., 40: 289-294.

Pinheiro, M.A.A. and A. Fransozo. - 1993. Relative growth of the speckled swimming crab Arenaeus cribrarius (Lamarck, 1818) (Brachyura, Portunidae), near Ubatuba, State of São Paulo, Brazil. Crustaceana, 65(3): 377-389.

Regnault, M. - 1992. Effect of air exposure on nitrogen metabolism in the crab Cancer pagurus. J. Exp. Zool., 264: 372-380.

Robblee, M.B., T.R. Barber, P.R. Jr. Carson, M.J. Durako, J.W. Fourqurean, L.K. Muehlstein, D. Porter, L.A. Yarbro, R.T. Zieman and J.C. Zieman. - 1991. Mass mortality of the tropical sea-grass Thalassia testudinum in Florida Bay (USA). Mar. Ecol. Prog. Ser., 71: 297-299.

Ryer, C.H., J. van Montfrans and R.J. Orth. - 1990. Utilization of a sea-grass meadow and tidal marsh creek by blue crabs Callinectes sapidus. II. Spatial and temporal patterns of molting. Bull. Mar. Sci., 46(1): 95-104.

Sampedro, M.P., E. González-Gurriarán, J. Freire and R. Muiño. 1999. Morphometry and sexual maturity in the spider crab Maja squinado (Decapoda; Majidae) in Galicia, Spain. J. Crust. Biol., 19(3): 578-593.

Sokal, R. and F.J. Rohlf. - 1995. Biometry. Third Edition (Third Printing). Freeman, New York.

Stachowitsch, M. - 1984. Mass mortality in the Gulf of Trieste: the course of community destruction. P.S.Z.N.I. Mar. Ecol., 5(3): 243-264.

Stoddart, D.R. - 1962. Catastrophic storm effects on the British Honduras reefs and cays. Nature, 196: 512-515.

Tsuchiya, M. - 1983. Mass mortality in a population of the mussel Mytilus edulis L., caused by high temperature on rocky shores. J. Exp. Mar. Biol. Ecol., 66: 101-111.

Valdez-Muñoz, E. - 1986. Distribución de los braquiuros (Crustacea: Brachyura) en la zona costera de Punta del Este, Cuba. Poeyana, 323: 1-19.

Vermeer, G.K. - 1987. Effects of air exposure on dessication rate, hemolymph chemistry and escape behavior of the spiny lobster, Panulirus argus. Fish. Bull., 85: 45-51.

Woodbury, B.D. - 1986. The role of growth, predation, and habitat selection in the population distribution of the crown conch Melongena corona Gmelin. J. Exp. Mar. Biol. Ecol., 97: 1-12.

Scient. ed.: J.B. Company

Received September 22, 2005. Accepted July 5, 2006.

Published online January 23, 2007. 